\title{
The benefit and cost of winner-picking: Redistribution vs. Incentives*
}

\author{
Axel Gautier \\ University of Bonn, Department of Economics \\ Florian Heider ${ }^{\dagger}$ \\ Department of Finance, Stern School of Business, New York University
}

October 2002

\footnotetext{
*We would like to thank Ron Anderson, Sudipto Bhattacharya, Patrick Bolton, Francis Bloch, Bernard Caillaud, Jacques Crémer, Kose John, Holger Müller and Daniel Wolfenzon for their comments. We also are grateful for the comments by seminar participants at the LSE-FMG (Lunchtime Seminar), IRES (Louvain-la-Neuve), Namur, Liège, HEC (Jouy-en-Josas), HEC (Montreal), Bocconi, NYU, IMF, Mannheim, Bonn, and at the following conferences: AFFI, ESEM, EFA (especially our discussant Robert Marquez), ESSFM (Gerzensee), EFMA and German Finance Association. We are grateful for the financial support from the Belgian Program on Inter-University Poles of Attraction (PAI nb. P4/01) at IRES (Université catholique de Louvain), our previous institution. Heider also thanks the Belgian National Fund for Scientific Research (FNRS) for its generosity and the FMG at the London School of Economics for its hospitality. The usual disclaimer applies.

${ }^{\dagger}$ Corresponding author: 44 West 4th. St., Suite 9-190, New York, NY 10012, USA; Tel.: +1 2129980311 , Fax: +1 212995 4233, email: fheider@stern.nyu.edu
} 


\title{
The benefit and cost of winner-picking: Redistribution vs. Incentives
}

\begin{abstract}
A multi-divisional firm can engage in "winner-picking" to redistribute scarce funds efficiently across divisions. But there is a conflict between rewarding winners (investing) and producing resources with which to reward winners (incentives). Managers in winning divisions are tempted to free-ride on resources produced by managers in loosing divisions whose incentives to produce resources, anticipating their loss, are also weakened. Corporate headquarter's investment and incentive policies are therefore inextricably linked and have to be treated as jointly endogenous. The analysis links corporate strategy, compensation and the value of diversification to the characteristics of multi-divisional firms.
\end{abstract}

JEL-Classification: G31, G34, L23 
The presence of large conglomerates is a dominant feature of advanced economies. In 1992, $88 \%$ of the 500 largest US public companies, producing three-quarter of the output of all US public companies, are conglomerates operating in more than one line of business (Montgomery (1994)). It has been argued that a key advantage of such firms is the value-enhancing reallocation of scare resources across divisions, i.e. a "smarter-money" or "winner-picking" effect (Alchian (1969), Williamson (1975) and, more recently, Stein (1997)). ${ }^{1}$ This paper points out that such winner-picking has innate agency costs when the funds with which to reward winners ex-post, must be produced ex-ante by division managers. Managers in winning divisions are tempted to free-ride on resources produced by managers in loosing division whose incentives to produce resources, anticipating their loss, are also weakened.

The model introduces moral-hazard with explicit incentive contracting at the division level to winner-picking in multi-divisional firms. Division managers' unobservable effort increases the amount of scarce resources available for redistribution. Headquarter's discretionary reallocation decision links divisions even if they are technologically independent. On the one hand, it is impossible for a headquarter that maximizes total firm value to fully commit not to intervene ex-post if a strong division needs resources and a weak division has them available. On the other hand, headquarter's ex-post reallocation creates negative effort externalities among division managers which hurts the production of resources. As a result, headquarter's investment policy (to pick winners or not) and its incentive policy (how to compensate division managers) are inextricably linked and have to be treated as jointly endogenous. In comparison, we show that in single-divisional firms, it is possible to separate investment from incentives although headquarter, as the asset owner, could still intervene ex-post in the division's production process, e.g. to liquidate.

Our approach confirms that strong unrelated, but also strong related diversification, hurts performance. Moderate related diversification however improves performance. We propose a number of new testable implications. For example, multi-divisional firms that operate similar but technologically independent divisions should either have a very balanced or a very unbalanced portfolio of divisions. If they do not, they face a dilemma: ex-post redistribution is attractive but not attractive enough to overcome ex-ante agency costs. Furthermore, the agency cost of "winner-picking" may i) lead to managers being paid more than their productivity or the profitability of their division warrant and ii) push headquarter into not incentivizing managers of strong divisions. Finally, we point out that rewarding divisional managers with options can reduce the agency cost of winner-picking.

Gertner et al. (1994) were the first to observe that a key difference between external and internal capital markets is that in the latter the financier, i.e. corporate headquarter, has unconditional property rights over investors', i.e. division managers', assets. The advantage is that the financier has stronger monitoring incentives. The disadvantage is that the financier cannot commit not to

\footnotetext{
${ }^{1}$ See Stein (2001) for a survey of the literature on investment inside firms.
} 
intervene ex-post which in turn discourages investors to undertake costly but value-enhancing actions. Their paper however does not consider winner-picking. ${ }^{2}$ In Stein (1997), corporate headquarter's asset ownership allows it to engage in winner-picking, but there is no agency cost since divisional managers are assumed to be passive. ${ }^{3}$

In Scharfstein and Stein (2000), corporate headquarter's assets ownership makes it vulnerable to wasteful influence activities by division managers and in Rajan et al. (2000) corporate headquarter uses its allocative authority to minimize wasteful bargaining among division managers. The result is that headquarter does not maximize value but inefficiently cross-subsidizes divisions. Our analysis abstracts from such allocation problems or "corporate socialism" and instead focuses on the impact of a well-functioning internal capital market operated by a value maximizing headquarter on division managers' incentives.

The agency cost of winner-picking is a result of both, taking funds away from losers and giving funds to winners. The "more money to winners" effect is different form Jensen (1986) free-cash flow problem in conglomerates since the funds are not diverted or sub-optimally invested. The funds are used to bail out managers in profitable but momentarily resource-constrained divisions. Anticipating the bail-out, these managers have less incentives to produce the resources themselves. ${ }^{4}$

The "less money to losers" effect is also different from the agency cost of winner-picking identified in Brusco and Panunzi (2000). In their paper, a division manager enjoys a private benefit on every dollar generated in his division. Under winner-picking he will not derive the same private benefits since some dollars are transferred to more profitable divisions elsewhere in the firm. Anticipating this, he works less to generate those dollars. Their analysis has the property i) that division managers always chose effort independently from each other and ii) that the value of a multi-divisional firm is independent of the ex-ante differences across divisions. Our analysis however argues that cost of winner-picking is the interdependence of division managers' effort while the benefit of winner picking is the value enhancing exploitation of ex-ante productivity differences across divisions. ${ }^{5}$

Section 1 introduces the model and section 2 analyzes single-divisional firms as a benchmark. Section 3 considers no winner-picking and section 4 considers winner-picking in a multi-divisional

\footnotetext{
${ }^{2}$ See also Aghion and Tirole (1997) for a similar analysis outside the context of internal capital markets.

${ }^{3}$ Stein (2002) introduces active managers but the focus is on information production. The paper explains that centralized information gathering does better than decentralized gathering if information is "hard", i.e. if it can be credibly passed along. Inderst and Laux (2000) examine the role of capital budgeting on information production and show that centralized information gathering is at a disadvantage if divisions start with different capital endowments.

${ }^{4}$ Gromb and Scharfstein (2002) have a similar effect: a multi-divisional firm cannot commit not to retain a high-ability worker who happens not to have had success. Knowing this, he has low incentives to work hard.

${ }^{5}$ Rotemberg and Saloner (1994) argue that an internal capital market creates synergies between risky projects leading to safer overall outcomes. This creates an agency cost since division managers, being compensated only when their project is implemented, have a preference for risky outcomes.
} 
firm. Section 5 discusses our model and presents extensions. Section 6 concludes.

\section{The Model}

Our model combines winner-picking and moral-hazard in a multi-divisional firm. The winner-picking aspect follows Stein (1997) and the moral-hazard aspect is as in Tirole (2001). Headquarter maximizes value and owns all productive assets but it has no expertise in managing them so that it must employ self-interested managers to run the divisions. All parties are risk-neutral and the risk-free interest rate is normalized to zero.

Production in each division $i$ can last for two periods, from $\mathrm{t}=0$ to $\mathrm{t}=1$ and from $\mathrm{t}=1$ to $\mathrm{t}=2$. If the manager of division $i$ exerts effort during the first production period, e.g. at $\mathrm{t}=0.5$, then the division has assets worth 1 at the end of the period with probability $p$ and worth 0 with probability $(1-p)$. If he does not exert effort the probabilities are $q<p$ and $(1-q)$ respectively. If the manager exerts effort he incurs a private cost $c{ }^{6}$ Second period production in a division occurs only if assets worth 1 are present at $\mathrm{t}=1$. If production continues for a second period, a division's assets are worth $\gamma_{i} \alpha$ at the end of the second period, $t=2$, when production ends and the division is liquidated. The success probabilities $p$ and $q$ are identical and independent across divisions (we allow for correlation in section 5.3), $\alpha$ represents the common second period productivity and $\gamma_{i}$ represents the extra productivity of division $i$.

We assume that unless all divisions succeed in the first period, headquarter cannot continue all of them since it has no access to external capital markets at $t=1 .^{7}$ To enable headquarter to pick winners, i.e. to allocate assets to those divisions which are the most productive in the second period, we assume that headquarter knows which divisions failed and which succeeded in the first period and how productive divisions are in the second period. ${ }^{8}$

Table I shows how headquarter can pick winners by having an internal capital market at $\mathrm{t}=1$. Suppose there are two divisions, $i=1,2$, one strong one and one weak one, e.g. $\gamma_{1}>\gamma_{2}$. The columns

\footnotetext{
${ }^{6}$ The specification is isomorphic to a model in which the agent enjoys private benefits $b=-c$ if he chooses no effort/shirk/misbehave.

${ }^{7}$ All we need is that headquarter cannot always continue all divisions. Without scarce resources there is no scope for winner picking. Scharfstein and Stein (2000) show how an agency problem between outside investors and headquarter affects the agency problem between headquarter and division managers. Inderst and Müller (2003) consider the difference between single- and multi-divisional with respect to debt finance. The advantage of the latter is that they can pool cashflows across divisions which reduces liquidity default. The disadvantage is that this exacerbates the free-cash flow problem which increases strategic default. De Motta (2002) argues that division managers may free-ride on the perception of the multi-divisional firm as a whole by external capital markets.

${ }^{8}$ In fact, we make assumptions that are in the spirit of (Stein, 1997, p. 117) except that we we simplify them (full information, no access to external capital markets) in order to be able to introduce moral-hazard and explicit incentive contracting at the divisional level.
} 


\begin{tabular}{|c|c|c|c|}
\hline $\begin{array}{l}\text { Both divisions } \\
\text { succeed }\end{array}$ & $\begin{array}{l}\text { Only strong divi- } \\
\text { sion } 1 \text { succeeds }\end{array}$ & $\begin{array}{l}\text { Only weak divi- } \\
\text { sion } 2 \text { succeeds }\end{array}$ & $\begin{array}{l}\text { Neither division } \\
\text { succeeds }\end{array}$ \\
\hline $\begin{array}{l}\text { continue both } \\
\text { continue } 1 \text {, stop } 2 \\
\text { stop } 1 \text {, continue } 2 \\
\text { stop both }\end{array}$ & $\begin{array}{l}\text { continue } 1, \text { stop } 2 \\
\text { stop } 1, \text { continue } 2 \\
\text { stop both }\end{array}$ & $\begin{array}{l}\text { stop } 1 \text {, continue } 2 \\
\text { continue } 1 \text {, stop } 2 \\
\text { stop both }\end{array}$ & stop both \\
\hline
\end{tabular}

Table I: Internal capital market: possible strategies (winner-picking in italics)

represent the four situations headquarter can encounter at $t=1$ depending on how divisions performed in the first period. The rows show headquarter's investment possibilities. In the best case, both divisions did well and there are enough assets to continue production in both divisions. Alternatively, headquarter could also stop production at $\mathrm{t}=1$ and liquidate a successful division's assets for their full worth 1 . In the worst case, both divisions did badly, assets are worth zero and production has to stop in both divisions. The interesting case is when one division did well and the other did badly so that headquarter can only continue production in one division either by continuing the successful division or by transferring assets and continuing the unsuccessful division.

Since headquarter knows that second period production is more productive in division 1, it would a priori always want to continue the strong division 1 even if only the weak division succeeded. The investment policy in italics in table I represents such winner-picking.

Effort is not observable so that there is a moral-hazard problem between headquarter and divisional managers. Headquarter incentivizes divisional managers to provide effort by giving them incentive contracts before production starts at $t=0$. We assume that intermediate production results and headquarter's investment decision at $\mathrm{t}=1$ are observable but not verifiable so that the incentive contracts cannot be contingent on them. ${ }^{9}$ If intermediate production results and investment decisions were contractible then there would be no role for corporate headquarter.

Incentive contracts can however be contingent on the liquidation value of assets. ${ }^{10}$ For expositional clarity we assume for the moment that the incentive contract of manager $i$ is contingent on the liquidation value of his division $i$ 's assets. His contract then specifies two payments: a fraction $W_{i}$ $\in[0,1]$ if headquarter discontinues and liquidates his division at $\mathrm{t}=1$ and a fraction $\delta_{i} \in[0,1]$ if headquarter continues his division until $\mathrm{t}=2$.

We interpret $W_{i}$ as compensation for being liquidated early such as severance pay or "golden parachutes". The fraction $\delta_{i}$ represents standard performance pay such as a continuation reward or a bonus. In section 5.1) we also consider incentive contracts based on total firm value such as shares or

\footnotetext{
${ }^{9}$ The assumption is standard and captures the notion that outsiders such as courts have less information than the contracting parties (see for example Grossman and Hart (1986)).

${ }^{10}$ The assumption is also standard and captures the notion that asset sales to outsiders are verifiable (see for example Hart and Moore (1998)).
} 
options. We show that there will always be an agency cost as long as winner-picking affects managerial compensation at all.

Figure 1 summarizes the sequence of events in our model.

\begin{tabular}{lll} 
First production period & \multicolumn{2}{c}{$\begin{array}{l}\text { Second produc- } \\
\text { tion period }\end{array}$} \\
$\begin{array}{l}\text { Headquarter gives in- } \\
\text { centive contracts to } \\
\text { divisional managers. }\end{array}$ & $\begin{array}{l}\text { Divisional managers } \\
\text { exert effort. }\end{array}$ & $\begin{array}{l}\text { Intermediate resources Refinanced divisions } \\
\text { realized. Headquarter } \\
\text { refinances or liquidates } \\
\text { divisions. }\end{array}$
\end{tabular}

Figure 1: The timing of events

\section{Single-divisional firms}

In this section we explore the moral-hazard problem between headquarter and a division manager in a firm with one division only. With just one division, there cannot be any winner-picking and consequently there are no agency costs over and above the rent the agent must earn in any moralhazard problem in return for his production effort. In particular, we show that the possibility of ex-post intervention by the owner of production assets does not add any new distortions.

To fix ideas, we initially present the hypothetical First-Best situation: what if headquarter could dictate managerial effort so that there is no moral-hazard problem? Then, we move to the SecondBest situation where the division manager must be induced to exert his effort. Finally, we introduce a benchmark for assessing the efficiency of winner-picking by asking: what is the value of two independent firms with one division each?

\subsection{First Best: No moral-hazard}

Suppose for a moment that headquarter not only decides whether to continue the production process or to liquidate its assets, but it can also impose the effort level on managers, i.e. effort is observable and contactable. In that case, headquarter acts as if it were the principal and the agent at the same time and thus fully internalizes the impact of its decisions. The continuation decision is efficient: production continues if and only if there is positive NPV in the second period, $\gamma_{i} \alpha \geq 1$. Headquarter exerts effort if and only if the extra likelihood of success exceeds the cost of effort, $p-q \geq c$.

Proposition 1 formally states the First Best situation in a single divisional firm without moralhazard. 
Proposition 1 In a firm with one division only and no moral-hazard between headquarter and division manager, production continues iff it has positive $N P V$ in the second period, $\gamma_{i} \alpha \geq 1$, and high effort occurs in the first period iff its benefit exceeds its cost, $p-q \geq c$.

Proof: In the appendix.

\subsection{Second Best: Simple managerial moral-hazard}

When effort is not observable, then there is moral-hazard since headquarter must incentivize the manager to exert effort.

If production was not successful in the first period then headquarter has no choice: production cannot continue for another period. But if it was successful then headquarter can either continue production for a second period and obtain the net continuation value $C\left(\delta_{i}\right)=\left(1-\delta_{i}\right) \gamma_{i} \alpha$, or it can stop production and obtain the net liquidation value $1-W_{i}$. At $\mathrm{t}=1$, headquarter continues successful production iff the following continuation constraint is met:

$$
\underbrace{\left(1-\delta_{i}\right) \gamma_{i} \alpha}_{C_{i}\left(\delta_{i}\right)} \geq 1-W_{i}
$$

The continuation reward $\delta_{i}$ and the severance pay $W_{i}$ that headquarter chooses ex-ante to incentivize his manager thus affect its ex-post investment decision. For example, if headquarter decids on a large continuation benefit relative to severance pay, $\delta_{i} \geq W_{i}$, then headquarter underinvest in second period production.

In order to determine the incentive pay for the manager, we must turn to his incentive compatibility constraints. Conditional on headquarter continuing successful production in a single divisional firm the manager exerts effort iff: ${ }^{11}$

$$
p \gamma_{i} \alpha \delta_{i}-c \geq q \gamma_{i} \alpha \delta_{i}
$$

Suppose headquarter wants managerial effort and wants to continue successful production. It pays the smallest possible incentive compatible continuation reward $\delta_{i}=\frac{c}{(p-q) \gamma_{i} \alpha}$ and consequently decides to continue iff

$$
\left(1-\frac{c}{(p-q) \gamma_{i} \alpha}\right) \gamma_{i} \alpha \geq 1-W_{i}
$$

\footnotetext{
${ }^{11}$ Conditional on liquidating successful production, the manager exerts effort iff $p W_{i}-c \geq q W_{i}$. We will shortly rule out such cases by assuming that second period production has positive NPV, $\gamma_{i} \alpha \geq 1$.
} 
Although investment decisions cannot be contractually fixed, headquarter can perfectly commit itself ex-ante to continuation by granting a very large severance pay, e.g. $W_{i}=1$. Conditional on continuation, headquarter thus wants his manager to exert effort if $p \gamma_{i} \alpha\left(1-\frac{c}{(p-q) \gamma_{i} \alpha}\right) \geq q \gamma_{i} \alpha$, which simplifies to $\gamma_{i} \alpha \frac{p-q}{p} \geq \frac{c}{p-q}$.

The following proposition shows that, as in the First-Best case and despite managerial moralhazard, headquarter's investment decision is efficient.

Proposition 2 Production in a single divisional firm is continued for a second period iff is efficient to do so, i.e. iff $\gamma_{i} \alpha \geq 1$. Headquarter induces effort from his divisional manager when ratio of the cost of effort to its benefit is smaller than relative impact of effort, $\frac{c}{p-q} \leq \frac{p-q}{p}$.

Proof: Analogous to the proof of proposition 1 with $\delta_{i}=\frac{c}{(p-q) \gamma_{i} \alpha}$ instead of $\delta_{i}=\frac{c}{p \gamma_{i} \alpha}$ and $W_{i}=\frac{c}{(p-q)}$ instead of $W_{i}=\frac{c}{p}$.

The first part of proposition 2 shows that in a single divisional firm, headquarter's ex-post investment decision is always efficient. In a single divisional firm it is therefore possible to separate investments from incentives. The intuition is that by granting maximal severance pay to his manager, headquarter perfectly commits ex-ante to continue successful production for a second production period (Similarly, headquarter could perfectly commit to liquidate should it wish to do so).

The second part of proposition 2 confirms the separation of investment from incentives. There is moral-hazard between headquarter and his manager. To induce effort, headquarter must leave him some rent, $p \frac{c}{p-q}$. The condition in the second part of the proposition states that headquarter only concedes this rent if it is smaller than the net benefit of effort, $(p-q)$, independent of second period NPV.

Proposition 2 illustrates an important feature of our model. Although i) headquarter's investment decision cannot be contractually fixed and ii) there is managerial moral-hazard, there are no investment inefficiencies in a single divisional firm where by definition there cannot be any winner-picking. Moreover, the fact that headquarter as the asset owner can intervene ex-post in the production process has no impact on the manager's agency rent.

\subsection{A benchmark: No winner-picking, no extra agency costs}

In order to assess the ex-ante efficiency of winner picking we need a benchmark. First, to keep the subsequent analysis tractable we assume that managerial effort is optimal in a single-divisional firm.

Assumption $1 \frac{c}{p-q} \leq \frac{p-q}{p}<1$.

Then we assume that second period production has positive NPV. 


\section{Assumption $2 \gamma_{i} \alpha>1$.}

The consequence is that despite the agency cost $c\left(\frac{p}{(p-q)}-1\right)$ headquarter always wants to induce managerial effort and that successful first-period production should lead to continuation. The manager earns an expected payment $c \frac{p}{p-q}$ through his continuation reward $\delta_{i}=\frac{c}{(p-q) \gamma_{i} \alpha}$ (the off-equilibrium severance pay is set sufficiently high, e.g. $W_{i}=1$ ). Headquarter's profit, i.e. firm value, is

$$
V_{i}=p \gamma_{i} \alpha-p \frac{c}{p-q}
$$

In the subsequent sections, we only consider a firm with two divisions $i=1,2$. Hence, we simplify $\gamma_{2}=1, \gamma_{1}=\gamma$ and assume without loss of generality that $\gamma \geq 1$. The parameter $\gamma$ then describes the extra productivity in the second production period of the strong division 1 over the weak division 2 .

The value of two independent firms, one with a single strong division and one with a single weak division, is:

$$
V^{*}=V_{1}+V_{2}=p \gamma \alpha+p \alpha-2 p \frac{c}{p-q}
$$

The first term describes the expected revenue from production in the strong division, the second describes the expected revenue from production in the weak division and the third term describes the expected cost of inducing both managers to exert effort.

In the subsequent analysis, we will use the value $V^{*}$ as a benchmark representing the situation where there is no winner picking and hence no agency cost due to the redistribution of resources (over

and above the payment $p \frac{c}{p-q}$ necessary to induce effort in both divisions). Section 5.2 extends the benchmark to take into account trade among single-divisional firms.

\section{Multi-divisional firm: no redistribution}

We will show shortly that winner-picking, i.e. redistribution towards the strong division 1, creates an agency cost. However, headquarter does not necessarily have to redistribute. If the agency costs of winner-picking outweigh its investment benefits, then perhaps headquarter could simply decide not to pick winners?

In this section, we show that there is an agency cost even if headquarter decides that it does not want to pick winners. The mere fact that is could creates a commitment problem. In order to mitigate the commitment problem headquarter may have to either overcompensate the manager of the strong division or to not incentivize the manager of the weak division. 


\subsection{Headquarter's investment decision}

There are four situations, represented by the columns of table I, that headquarter can encounter after the first production period at $\mathrm{t}=1$. Either both divisions have succeeded, or just the strong division 1 or the weak division 2 has succeeded, or neither division has succeeded. In each situation headquarter has the investment choices shown in the rows of the table.

In order to carry out a policy of no-redistribution it must be optimal at $\mathrm{t}=1$ to continue production whenever it has succeeded given that second-period production has positive NPV (assumption 2), :

$$
C_{i}\left(\delta_{i}\right) \geq 1-W_{i} \quad i, j=1,2
$$

The conditions in (4) are the continuation constraints that we encountered already in the analysis of a single-divisional firm (1).

But if headquarter wants to carry out a policy of no redistribution then it must also prefer continuing successful production in each division to liquidating a successful division and refinancing another, unsuccessful division.

$$
C_{i}\left(\delta_{i}\right) \geq C_{j}\left(\delta_{j}\right)-W_{i} \quad i, j=1,2
$$

The transfer constraints (5) are more stringent than the continuation constraints (4) when second period production is profitable, i.e. $C_{i}\left(\delta_{i}\right)-1>0$. The availability of other positive NPV projects can make it more difficult in a multi-divisional firm for headquarter to commit not to intervene ex-post than in a single-divisional firm. Even a maximum severance pay, $W_{i}=1$, may no longer be enough to perfectly commit not to intervene ex-post since the motive for intervention is refinancing another profitable division instead of mere liquidation as in a single-divisional firm. ${ }^{12}$

\subsection{Managers' effort decision}

Given that headquarter does not redistribute resources between production periods at $t=1$, the manager of division $i$ exerts effort when

$$
p \gamma_{i} \alpha \delta_{i}-c \geq q \gamma_{i} \alpha \delta_{i}
$$

\footnotetext{
${ }^{12} \mathrm{An}$ arbitrarily small severance pay is not enough to commit not to redistribute although, a priori, it seems that it could. If headquarter liquidates a successful division $i$, it must pay its manager the severance pay so that there are not enough funds available to refinance division $j$. But at $\mathrm{t}=1$ headquarter could offer the manager to postpone his severance pay until the end of the second production period, $\mathrm{t}=2$. The manager is indifferent and headquarter benefits as long as $C_{i}<C_{j}-W_{i}$. The severance pay that does not lead to redistribution via renegotiation must therefore satisfy the transfer constraints (5).
} 
In a multi-divisional firm, a manager's incentive problem is identical to his incentive problem in a a single-divisional firm if headquarter chooses not to redistribute resources, i.e. if there is no winner-picking.

\subsection{Can not picking winners do worse than the benchmark $V^{*}$ ?}

Having described headquarter's investment decision to not redistribute and managers' incentive decision to exert effort, we now ask: what is the value of the firm when headquarter induces both managers to exert effort but decides not to redistribute resources between the production periods?

Given the optimality of effort (assumption 1), it suffices to consider the case where both managers exert effort. If they did not, a multi-divisional firm that chooses not to pick winners would automatically do strictly worse than the benchmark $V^{*}$.

Headquarter solves at $\mathrm{t}=0:^{13}$

$$
\begin{aligned}
& \max _{\delta_{1}, \delta_{2}, W_{1}, W_{2}} p^{2}\left(C_{1}\left(\delta_{1}\right)+C_{2}\left(\delta_{2}\right)\right)+p(1-p) C_{1}\left(\delta_{1}\right)+(1-p) p C_{2}\left(\delta_{2}\right) \\
& \text { subject to: } \\
& \begin{aligned}
C_{1}\left(\delta_{1}\right) & \geq 1-W_{1} & & \text { (Continuation Constraints) } \\
C_{2}\left(\delta_{2}\right) & \geq 1-W_{2} & & \\
C_{2}\left(\delta_{2}\right) & \geq C_{1}\left(\delta_{1}\right)-W_{2} & & \text { (Transfer Constraint) } \\
p \gamma \alpha \delta_{1}-c & \geq q \gamma \alpha \delta_{1} & & \text { (Incentive Constraints) } \\
p \alpha \delta_{2}-c & \geq q \alpha \delta_{2} & &
\end{aligned}
\end{aligned}
$$

Headquarter optimally chooses the continuation reward, $\delta_{2}=\frac{c}{(p-q) \alpha}$, and the severance pay, $W_{1}=$ 1 and $W_{2}=1$. Inspecting the incentive constraint for the manager in the strong division 1 and the transfer constraint we obtain the following result:

Proposition 3 No redistribution does worse than the benchmark $V^{*}$ iff the extra second period productivity in the strong division 1 is large, $\gamma>1+\frac{1}{\alpha}$.

Headquarter cannot fully commit not to redistribute towards the strong division 1 by using severance pay only, if the extra productivity of that division $\gamma$ is large. As $\gamma$ increases, the transfer constraint will eventually be binding even though $W_{1}=1$. To continue to commit not to redistribute and at the same time induce effort from both managers, headquarter must then overcompensate the manager of the strong division, i.e pay him more than his effort warrants, .

\footnotetext{
${ }^{13}$ Note that headquarter would never want to redistribute towards the weaker division 2 so that we can omit one transfer constraint.
} 
Figure 2 illustrates the proposition in a graph that plots the extra productivity of the strong division $\gamma$ against the overall productivity $\alpha$.

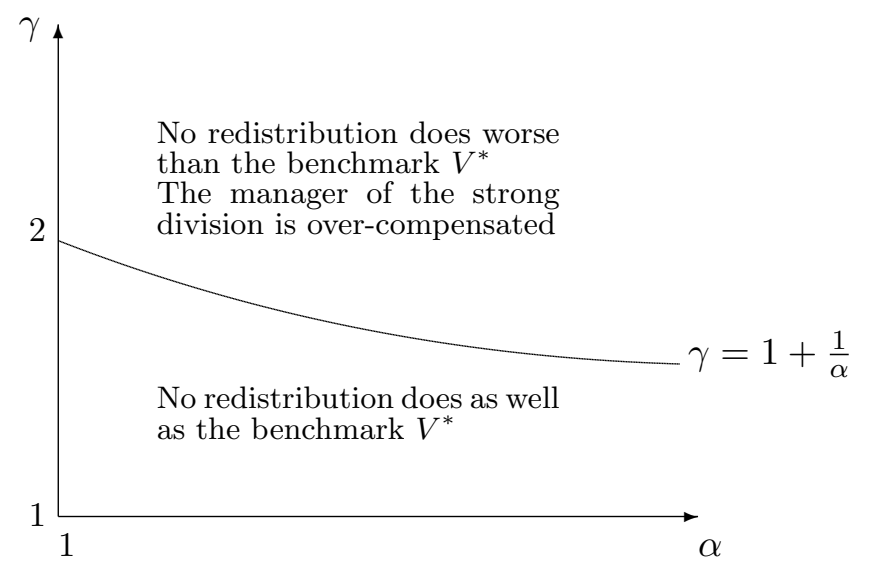

Figure 2: No redistribution does worse than the benchmark $V^{*}$ if the productivity difference across divisions is large

Instead of overcompensating the manager in the strong division 1, headquarter could alternatively decide not to induce managerial effort in the weak division 2. Saving the agency cost in the weak division makes it less attractive to redistribute towards the strong division, where there is still an agency cost, and hence makes it easier to commit not to intervene. But without managerial effort, second-period production, which has positive NPV, is also less likely.

Proposition 4 shows when the benefit of alleviating the commitment problem by not incentivizing the manager of the weak division outweighs the cost of inefficient production.

Proposition 4 If headquarter does not redistribute then it chooses not to induce managerial effort in the weak division if $i)$ the overall productivity is low, $\alpha<2\left(\frac{c}{p-q}\right)\left(\frac{p}{p-q}\right)$, and ii) if the extra productivity of the strong division 1 is high, $\gamma>\left(1+\frac{p-q}{p}\right)+\left(1-\frac{c}{p-q}\right) \frac{1}{\alpha}>1+\frac{1}{\alpha}$.

Proof: In the appendix.

Given that effort is desirable, part ii) of the proposition confirms that headquarter does not induce effort only if there is a commitment problem. Part i) adds that headquarter accepts no effort in the weak division only if the production inefficiency does not matter much in relation to the commitment problem, i.e. $\alpha$ is small relative to $\gamma$. 


\section{Multi-divisional firm: redistribution}

In this section we show that winner-picking will not always be optimal. Using the resources from the weak division to refinance the strong division creates several costs. First, it will be more difficult to incentivize the manager of the strong division. Second, there may be underinvestment since redistribution undermines the use of severance pay as a commitment to continuation. And third, headquarter may have to overcompensate the manager of the weak division in order to commit to refinance the strong division. In order to mitigate these costs of winner-picking, headquarter may choose not to incentivize the manager of the strong division.

\subsection{Headquarter's investment decision}

As described in the section on no-redistribution, headquarter can encounter four situations after the first production period at $\mathrm{t}=1$ (see table I). If headquarter now wants to carry out a policy of redistribution, we need to reconsider the situation when the strong division 1 failed but the weak division 2 succeeded. Continuing production now means that it must be optimal to continue the strong division as opposed to liquidate the weak division:

$$
C_{1}-W_{2} \geq 1-W_{2}
$$

Redistribution modifies the continuation constraint. In order to continue the strong division 1, headquarter must first shut down the weak division 2. Since the manager's division is liquidated despite having succeeded, he has a right to severance pay $W_{2}$. The consequence is that under redistribution, there will be inefficient continuation of the strong division 1 if its manager exerts effort, i.e. if $\delta_{1}>0$. Under redistribution, headquarter can no longer use severance pay to commit to continue the strong division efficiently since the pay is no longer incremental, i.e. it is no longer relevant. ${ }^{14}$

Picking the winner moreover requires that headquarter prefers continuing the strong instead of the weak division:

$$
C_{1}-W_{2} \geq C_{2}
$$

The transfer constraint under redistribution (9) is simply the opposite of the transfer constraint under no-redistribution (5). Note that with managerial effort, which itself is affected by redistribution

\footnotetext{
${ }^{14}$ In the practice of capital budgeting, the relevant cash-flows of an investment are determined by the incremental cash-flow principle which asks: what cash-flows are a direct consequence of the decision to undertake the project? Under redistribution, the severance pay is sunk when deciding whether to continue a failed strong division or to liquidate a successful weak division.
} 
as we shall see in the next section, the extra productivity of the strong division $1, \gamma$, may by itself not suffice to guarantee that headquarter wants to redistribute. ${ }^{15}$

\subsection{Managers' effort decision}

Under winner-picking, the manager of the strong division 1 is always refinanced. He not only gets his continuation reward $\delta_{1}$ if he succeeded in the first production period but also if he failed provided that the weak division 2 succeeded. The probability of him receiving $\delta_{1}$ therefore depends not only on his own but also on the other manager's effort.

Given that the manager in the weak division 2 exerts effort, the manager in the strong division 1 receives $\delta_{1}$ with probability $p+(1-p) p$ if he exerts effort too and with probability $q+(1-q) p$ if he does not. Conditional on effort in the weak division 2, the manager in the strong division 1 thus exerts effort when:

$$
[p+p(1-p)] \gamma \alpha \delta_{1}-c \geq[q+(1-q) p] \gamma \alpha \delta_{1}
$$

But conditional on no effort in the weak division 2, the manager in the strong division 1 exerts effort when:

$$
[p+p(1-q)] \gamma \alpha \delta_{1}-c \geq[q+(1-q) q] \gamma \alpha \delta_{1}
$$

The situation for the manager of the weak division 2 different. He is only refinanced if he successfully produced resources and if the strong division 1 does not need his resources. Should the strong division 1 need his resources, then the manager of the weak division 2 is liquidated in which case he receives his severance pay $W_{2}$.

Conditional on effort in the strong division 1, the manager of the weak division 2 therefore exerts effort too when

$$
p^{2} \alpha \delta_{2}+(1-p) p W_{2} \geq p q \alpha \delta_{2}+(1-p) q W_{2}
$$

and conditional on no effort in the strong division 1, the manager of the weak division 2 exerts effort when:

$$
q p \alpha \delta_{2}+(1-q) p W_{2} \geq q^{2} \alpha \delta_{2}+(1-q) q W_{2}
$$

\footnotetext{
${ }^{15}$ Again, renegotiation prevents that an arbitrarily small severance pay makes redistribution infeasible. If $W_{2}>0$ and only the weak division 2 succeeds then headquarter proposes to postpone the payment of $W_{2}$ until the end of the second production period to be able to refinance the strong division 1 . The manager is indifferent and headquarter benefits as long as $C_{1}-W_{2} \geq C_{2}$ which is the transfer constraint (9).
} 
Proposition 5 shows that when compensation is based on divisional performance, winner-picking makes it more difficult to induce effort in the strong but not in the weak division. Moreover, the extra rent the manager of the strong division captures decreases if there is no effort in the weak division.

Proposition 5 Redistribution leads to extra agency costs: the manager in the strong division who gains resources requires a larger rent to exert effort than in a single-divisional firm. Moreover, the manager of the weak division who looses resources requires at least the same rent as in a singledivisional firm to exert effort.

Proof: In a single-divisional firm, a manager requires an expected payment $\frac{p}{p-q} c$ to induce effort. With redistribution, the smallest continuation reward that motivates managers is given when the incentive constraints (10) to (13) bind. The manager of the strong division then receives an expected payment of $\left(1+\frac{1}{1-p}\right) \frac{p}{p-q} c$ if the manager of the weak division exerts effort, or $\left(1+\frac{1}{1-q}\right) \frac{p}{p-q} c$ if he does not. Using (12) as an equality, we can show that the manager of the weak division receives an expected payment of $p^{2} \alpha\left[\frac{c}{(p-q) p \alpha}-\frac{1-p}{p \alpha} W_{2}\right]+(1-p) p W_{2}=p \frac{c}{p-q}$ if the manager of the strong division exerts effort, or, using (13), $q p \alpha\left[\frac{c}{(p-q) q \alpha}-\frac{1-q}{q \alpha} W_{2}\right]+(1-q) p W_{2}=p \frac{c}{p-q}$ if he does not.

The key is that under winner-picking, it is not possible for incentive purposes to ascertain ex-post in a verifiable way whether production in a strong division continued because of previous success in that division or because of previous success elsewhere in conjunction with redistribution. Incentives in a weak division are unaffected since production in a weak division continues only if there has been previous success in that division. ${ }^{16}$

\subsection{Will picking winners always do better than the benchmark $V^{*}$ ?}

Suppose that headquarter wants to induce effort in both divisions. Given the new continuation, transfer and incentive constraints, it solves at $\mathrm{t}=0$ :

\footnotetext{
${ }^{16}$ We will show below that when the incentive constraints are not redundant, they will bind at the optimum.
} 
$\max _{\delta_{1}, \delta_{2}, W_{2}} p^{2}\left(C_{1}\left(\delta_{1}\right)+C_{2}\left(\delta_{2}\right)\right)+p(1-p) C_{1}\left(\delta_{1}\right)+(1-p) p\left(C_{1}\left(\delta_{1}\right)-W_{2}\right)$

subject to:

$\begin{aligned} C_{1}\left(\delta_{1}\right) & \geq 1 & & \text { (Continuation Constraints) } \\ C_{2}\left(\delta_{2}\right) & \geq 1-W_{2} & & \\ C_{1}\left(\delta_{1}\right)-W_{2} & \geq C_{2}\left(\delta_{2}\right) & & \text { (Transfer Constraint) } \\ {[p+p(1-p)] \gamma \alpha \delta_{1}-c } & \geq[q+(1-q) p] \gamma_{1} \alpha \delta_{1} & & \text { (Incentive Constraints) } \\ p^{2} \alpha \delta_{2}+(1-p) p W_{2} & \geq p q \alpha \delta_{2}+(1-p) q W_{2} & & \end{aligned}$

Disregard the continuation and transfer constraints for a moment for a moment so that $\delta_{1}$ and $\left(W_{2}, \delta_{2}\right)$ are given by the incentive constraints. The value of the multi-divisional firm then is:

$$
V_{e, e}^{t}=\left(2 p-p^{2}\right) \gamma \alpha+p^{2} \alpha-p \frac{c}{p-q}\left(1+\frac{1}{1-p}\right)-p \frac{c}{p-q}
$$

The first and second term are the expected benefit from second period production in the strong and weak division respectively. The third and fourth term are the expected cost of inducing effort in the strong and the weak division. Redistribution has no effect on the cost in the weak division but it increases the cost in the strong division by $1+\frac{1}{1-p}$.

The multi-divisional firm does better than the benchmark when $V_{e, e}^{t}>V^{*}$, i.e. when

$$
(1-p) p(\gamma-1) \alpha>\frac{p}{1-p} \frac{c}{p-q}
$$

The term on the left-hand side is the benefit of winner-picking. With probability $(1-p) p$ there are only resources in the weak division and by redistributing, headquarter raises productivity from $\alpha$ to $\gamma \alpha$. The term on the right-hand side is a cost of winner-picking. It is more difficult to incentivize the manager of the strong division since he knows that headquarter refinances his division even if there was previous poor performance.

The following proposition fully solves (14) to show that under redistribution headquarter may also have to overcompensate the manager in the weak division and, moreover, may not even be able to induce effort in both divisions.

Proposition 6 If headquarter redistributes then it can induce effort in both division only if $\gamma \geq$ $\frac{1}{\alpha}\left(1+\frac{c}{p-q} \frac{1}{1-p}\right)$. However, if $\gamma<1+\frac{c}{p-q} \frac{2 p-1}{p(1-p) \alpha}$ then headquarter must overcompensate the manager of the weak division.

Proof: In the appendix. 
Headquarter may have to overcompensate the manager of the weak division in order to commit to redistribute when the extra productivity of the strong division $\gamma$ is low so that production in that division is not very attractive due to the high rent for its manager (see the transfer constraint (9)). Moreover, it is simply not feasible to continue the strong division 1 when its overall productivity $\gamma \alpha$ is low (see the continuation constraint (8)).

In order to avoid the costs of effort in the strong division (extra rent, overcompensation or inefficient continuation) headquarter could decide not to incentivize the manager of the strong division. But the disadvantage then is that there will be less second period production.

Proposition 7 shows when the costs of effort in the strong division outweigh the production inefficiency.

Proposition 7 If headquarter redistributes then it prefers not to incentivize the manager of the strong division when $\gamma<\frac{-p}{1-p}+\left(\frac{c}{p-q} \frac{p(2-p)}{(p-q)(1-p)^{2}}\right) \frac{1}{\alpha}$. When $\alpha>\frac{c}{p-q}\left(\frac{p(2-p)}{(1-p)(p-q)}-\frac{2 p-1}{p}\right)$ the condition weakens to $\gamma<\frac{p q}{p-q+p q}-\left(\frac{c}{p-q} \frac{p(1+p)}{(1-p)(p-q+p q)}\right) \frac{1}{\alpha}$. Headquarter always incentivizes the manager of the weak division.

Proof: In the appendix.

The last part of the proposition follows from the fact that incentivizing the manager of the weak division costs as much as in a single-divisional firm and that effort was desirable in that case (assumption 1).

The first condition of the proposition is obtained by asking: when does headquarter want to incentivize only the manager of the weak division (without ever overcompensating him), i.e. when is $V_{n, e}^{t}>V_{e, e}^{t}\left(\right.$ where $V_{n, e}^{t}$ is the value when there is redistribution but no effort in the strong division)? ${ }^{17}$ The condition can be written as

$$
p \frac{c}{p-q}\left(1+\frac{1}{1-p}\right)>(p-q)[\gamma \alpha-p(\gamma-1) \alpha]
$$

The left-hand side is the gain of not having to incentivize the manager in the strong division. The right-hand side is the loss in production efficiency. Without effort, second-period production occurs less often $(p-q)$ in the strong division $(\gamma \alpha)$ but redistribution from the weak division, and hence winner-picking, occurs more often $(-p(\gamma-1) \alpha)$. The efficiency loss matters less when $\gamma$ and $\alpha$ are low.

When the weak division is quite productive but the extra productivity of the strong division is small, then headquarter must incur the cost of overcompensating the manager in the weak division in order to still commit to redistribute. Not incentivizing the manager of the strong division is then even more attractive (i.e. the second part of the proposition).

\footnotetext{
${ }^{17}$ The value $V_{n, e}^{t}$ is derived in the proof of proposition 7 in the appendix.
} 
We can now examine when winner-picking without effort in the strong division does better than the benchmark, i.e. when is $V_{n, e}^{t}>V^{*}$ ? The condition can be rewritten as:

$$
(1-p) q(\gamma-1) \alpha+p \frac{c}{p-q}>(p-q) \alpha
$$

The first term on the left-hand side is the gain from winner-picking. The second term is the gain from incentivizing only one manager. The right-hand side is the loss in production efficiency due to no effort in the strong division (Note that the term is in $\alpha$ only due to redistribution).

Proposition 8 restates (16) and (18).

Proposition 8 Winner-picking picking does better than the benchmark $V^{*}$ only if the extra productivity of the strong division is sufficiently high: $\gamma>1+\left(\frac{c}{p-q} \frac{2 p-1}{(1-p) p}\right) \frac{1}{\alpha}$ or $\gamma>1+\left(\frac{c}{p-q} \frac{1}{(1-p)^{2}}\right) \frac{1}{\alpha}$.

Figure 3 illustrates our results. Winner-picking does better than the benchmark $V^{*}$ only if $\gamma$ lies above the thick curve (conditions (16) and (18)). The thin curve indicates whether headquarter incentivizes the manager of the strong division or not (condition (17)). Assumption 1 on the desirability of effort implies that for all productivity levels $\alpha$, the extra productivity of the strong division $\gamma$ must be sufficiently large before winner-picking overcomes its agency cost. In other words, the thick curve always intersects the y-axis above 1 .

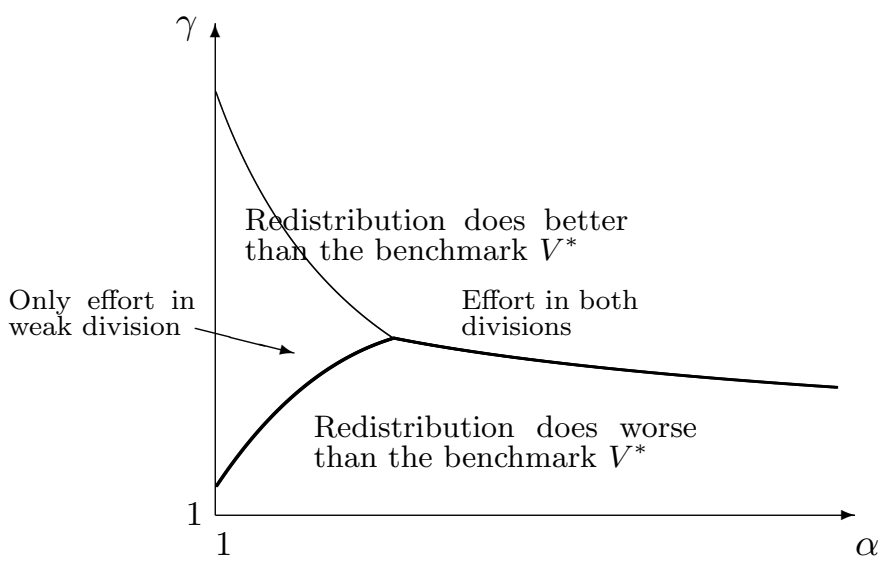

Figure 3: Redistribution does better than the benchmark $V^{*}$ only if the productivity difference across divisions is large

Ceteris paribus, winner-picking initially becomes less attractive as $\alpha$ increases due to the production inefficiency of no effort in the strong division. Eventually, headquarter incentivizes both managers and winner-picking becomes more attractive since the agency cost does not depend on productivity. 


\subsection{When does a multi-divisional firm do worse than the benchmark $V^{*}$ ?}

We now combine the analysis of the redistribution and the no-redistribution case to ask: when does the multi-divisional firm with an internal capital market do worse than the benchmark $V^{*}$ ?

Proposition 9 The multi-divisional firm does worse than the benchmark $V^{*}$ for intermediate differences in divisional productivity $\gamma$ and sufficiently high overall productivity, $\alpha>\frac{c}{p-q} \frac{p}{p-q}+q \frac{1-p}{p-q}$, if $\frac{c}{p-q}>(1-p)^{2}$.

Proof: The condition on $\alpha$ is obtained by comparing the condition in proposition 3 to (18). The condition on $c$ by comparing the condition in proposition 3 to (16).

Figure 4 illustrates the proposition. It is a combination of figures 2 and 3 . When the extra productivity of the strong division is low then the incentive cost of redistribution is large compared to its investment benefit so that headquarter prefers not to engage in winner-picking. When the extra productivity is large then the reverse holds. It is in the middle ground, provided that the overall productivity is large enough, that headquarter may not be able to reconcile its investment policy with its incentive policy since both redistributing and not redistributing has costs. Redistribution makes its more difficult to induce effort in the strong division and may even lead to headquarter choosing not to incentivize the manager of the strong division. No redistribution however is costly because headquarter then commits to an a priori inefficient investment policy by overcompensating the manager of the strong division.

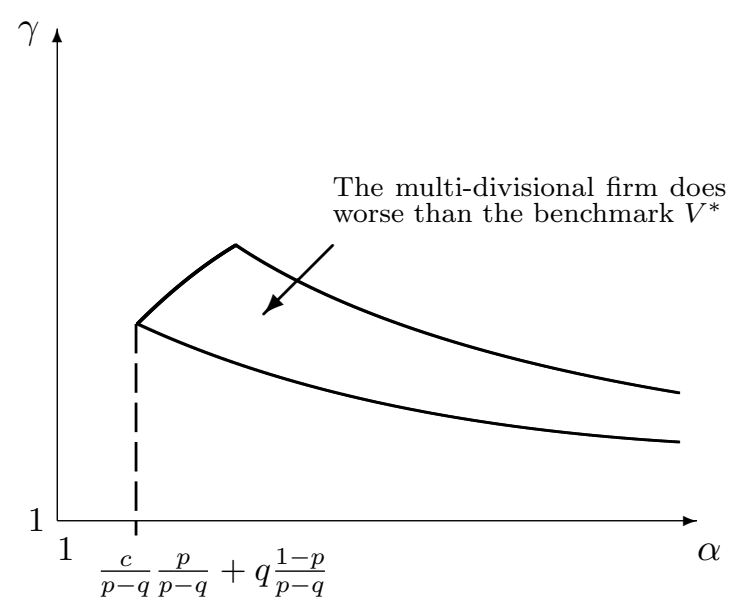

Figure 4: The multi-divisional firm does worse than the benchmark $V^{*}$ if the productivity difference across divisions is neither large nor small 


\section{Discussion}

In this section we address the issue of incentive contracts, of the value benchmark and of diversification. In addition, we discuss the empirical implication of our model.

\subsection{Managerial incentive contracts}

So far we showed that when headquarter has the possibility for winner-picking then it is more difficult to incentivize managers and it is more difficult to commit to an investment policy. The commitment problem resulted from the fact that a) current resources are scarce and do not suffice in view of positive NPV projects and b) winner-picking interferes with the "incremental cash-flow" principle of capital budgeting.

The results on commitment appear robust to different specifications of the incentive contract. First, unless headquarter has more resources available at $t=1$, the inability to fully commit ex-ante to an investment policy, e.g. through large severance pay, remains. If headquarter does however have more resources available then there is of course less scope for winner-picking in the first place. Second, unless headquarter can make expenses such as severance pay contingent on its investment policy, winner-picking will mean that cash-flows that were supposed to pertain only to division $i$ do matter for the decision to invest in division $j$.

To explore the robustness of the agency cost, suppose headquarter uses incentive compensation based on the value of the firm, such as shares, instead of compensation based on the value of divisions. Each manager of division $i$ now receives a fraction $\hat{\delta}_{i}$ of the total liquidation value of the firm at $\mathrm{t}=2$. Under winner-picking the strong division 1 is always continued so that total firm value is $\gamma \alpha+\alpha$ with probability $p^{2}$ and $\gamma \alpha$ with probability $2 p(1-p)$ if both managers exert effort. If only one of them exerts effort then the probabilities change to $q p$ and $[q(1-p)+p(1-q)]$ respectively. Condition on effort in division $j$, a manager of division $i$ prefers to exert effort when:

$$
p^{2} \hat{\delta}_{i}(\gamma \alpha+\alpha)+2 p(1-p) \hat{\delta}_{i} \alpha \geq q p \hat{\delta}_{i}(\gamma \alpha+\alpha)+[q(1-p)+p(1-q)] \hat{\delta}_{i} \alpha
$$

The rent necessary to incentivize a manager is at least

$$
p \frac{c}{p-q}\left(1+\frac{\gamma}{(1-p) \gamma+p}\right)
$$

which is smaller than the rent captured by the manager of the strong division 1 when compensation

is based on divisional value, $p \frac{c}{p-q}\left(1+\frac{1}{1-p}\right)$, but it is larger than the rent captured by the manager of the weak division 2 (or manager in a single-divisional firm), $p \frac{c}{p-q}$.

It is more difficult to incentivize the manager of the weak division since there is now free-riding. With shares, he receives compensation even if he failed in the first production period provided that the 
strong division succeeded. It is easier to incentivize the manager of the strong division since he now internalizes the effort of the other manager in the weak divisions (given the other division's success or failure, he now receives different payments depending on whether he himself succeeds nor not). But there is now also free-riding by him too.

Proposition 10 shows when headquarter prefers to link compensation to divisional value.

Proposition 10 When headquarter uses shares instead of divisional value then incentivizing both managers is more expensive if $\gamma>\frac{p}{1-p}$.

Proof: The expected cost of inducing both managers to work hard is $p \frac{c}{p-q}\left(2+\frac{1}{1-p}\right)$ when compensation is based on divisional value and it it $p \frac{c}{p-q}\left(2+\frac{2 \gamma}{(1-p) \gamma+p}\right)$ when compensation is based on total firm value. The result follows from checking when the latter exceeds the former.

When compensation is tied to divisional value, the agency cost results only from the behavior of the manager of the strong division. He receives the continuation reward more often. The cost therefore increases only in $p$. With shares the cost is due to free-riding and increases in both $p$ and $\gamma$. For example, the manager of the weak division is paid more often and his pay depends on total firm value which is a function of $\gamma$. As the extra productivity of the strong division $\gamma$ increases, share compensation will eventually become more costly than compensation based on divisional value.

Giving managers shares means giving them incentive contracts that are linear in firm value. Headquarter could also use more general, non-linear contracts such as combinations of shares and options. In the context of our model the most general incentive contract specifies a different fraction $\delta_{i, v}$ of firm value paid to the manager of division $i$ for each of four possible firm values: $v \in\{0, \alpha, \gamma \alpha, \gamma \alpha+\alpha\}$.

Due to limited liability, headquarter cannot pay anything if both divisions failed, $\delta_{i, 0}=0$. We can also set $\delta_{i, \alpha}=0$ since the weak division is never continued under winner-picking.

Proposition 11 shows that if winner-picking is not redundant then it leads to agency costs.

Proposition 11 Under winner-picking, it is more difficult to incentivize divisional managers as long as $\delta_{i, \gamma \alpha}>0$.

Proof: In the appendix.

As long as winner-picking affects incentive compensation there is an extra agency cost because headquarter's ex-post intervention introduces extra noise weakening the link between managerial effort and performance. When $\delta_{i, \gamma \alpha}=0$ then compensation depends only on the highest possible firm value. But it that case, first period production succeeded in both divisions and resources are not scarce so that there is no need for winner-picking. 
Compensation with $\delta_{i, \gamma \alpha}=0$ could be achieved by giving managers only share options. ${ }^{18}$ Rewarding divisional managers only with options appears increasingly unrealistic as the number of divisions grows. Suppose that headquarter oversees 10 divisions. The condition to avoid the agency cost of winner-picking is that all 10 managers are paid only in the unlikely event that all 10 divisions jointly succeed. Such a compensation plan is very unattractive for managers who want to consume also when firm value is not at its maximum. Another reason for $\delta_{i, \gamma \alpha}>0$ is that $1 \$$ paid out of division $i$ may not be identical to $1 \$$ paid out of division $j$, e.g. if managers have their human capital tied up in their division or if career prospects depend on divisional performance.

The implication that it is more difficult to incentivize divisional managers if there is redistribution is broadly consistent with recent empirical findings. Aggarwal and Samwick (2003) find a that higher diversification is associated with higher managerial compensation. Wulf (2000) documents a negative link between divisional investment sensitivity to profitability, which could reflect the extent of winnerpicking, and compensation. Bushman et al. (1995) show that division CEOs' compensation is based less on firm performance if there is less related and more unrelated diversification. We would expect winnerpicking to be less relevant for related diversification since liquidity shocks then affect all divisions at the same time (see also section 5.3). The last two studies also provide survey evidence that roughly $50 \%$ of division CEOs' annual bonuses are based on division performance and that $25 \%$ are based on firm performance.

Our analysis also produces the following new implications that await testing. Firms that redistribute may have compensation that is not closely tied to managerial productivity in weak divisions (overcompensation). Nor should those managers be granted large severance pay. Firms that do not redistribute may have compensation that is not closely tied to managerial productivity in strong divisions. Now, managers in weak divisions should be granted large severance pay. Moreover, in multidivisional firms with winner-picking, compensation should not be sensitive to average performance, but sensitive to very strong performance.

\subsection{Internal and external capital markets}

In this section we explore the robustness of our benchmark $V^{*}$. To sharpen the description of the conflict between winner-picking and its agency costs in a multi-divisional firm, we assumed that the benchmark case consists of single-divisional firms that do not interact. Without interaction, there is no redistribution and hence no associated agency cost.

Suppose now that the strong and the weak firm can trade on an external capital market. A weak

\footnotetext{
${ }^{18} \mathrm{An}$ option that is in the money only if both all divisions succeed achieves two goals: it eliminates free-riding and it makes the non-verifiability of production results (or of headquarter's investment decision, a weaker condition) inconsequential. Most executive stock options however seem to be granted at the money (e.g. Yermack (1995)).
} 
firm that succeeded in the first production period could offer to lend 1 unit of capital at a price $\tau$ to a strong firm that failed. The strong firm accepts the trade as long as $\left(1-\delta_{1}\right)(\gamma \alpha-\tau) \geq 0$ while the weak firm accepts as long as $\left(1-\delta_{2}\right) \tau \geq\left(1-\delta_{2}\right) \alpha$ so that there is trade if $\tau \in[\alpha, \gamma \alpha]$. In order to model capital market imperfections we introduce the parameter $\mu$. It is the probability with which a successful weak firm meets an unsuccessful strong firm when they are looking for each other in the market. If $\mu=0$ trade is impossible and if $\mu=1$ it is frictionless.

The manager of the strong firm anticipates that if he fails to produce any resources, there will be trade with a weak firm enabling him to continue production nevertheless. Conditional on effort in the weak firm, he exerts effort too when:

$$
p \gamma \alpha \delta_{1}+(1-p) \mu(\gamma \alpha-\tau) \delta_{1}-c \geq q \gamma \alpha \delta_{1}+(1-q) \mu(\gamma \alpha-\tau) \delta_{1}
$$

The second term on the left- and the right-hand side of the inequality is the manager's expected continuation benefit through trading.

Similarly, the manager of the weak firm anticipates that he will use his resources for trading rather than second period production. Conditional on effort in the strong firm, he exerts effort too when:

$$
p\left(\mu \tau \delta_{2}+(1-\mu) \alpha \delta_{2}\right)-c \geq q\left(\mu \tau \delta_{2}+(1-\mu) \alpha \delta_{2}\right)
$$

Proposition 12 shows that ex-post trade between the two single-divisional firms leads to agency costs in the borrowing strong firm.

Proposition 12 When the strong firm 1 trades with the weak firm 2, there is an extra agency cost in the strong but not in the weak firm. The rent to induce effort from the manager of the strong firm is: $p \frac{c}{p-q}\left(1+\frac{\mu(\gamma \alpha-\tau)}{p[\gamma \alpha+\mu(\tau-\gamma \alpha)]}\right)$.

Proof: If headquarter induces effort in a single-divisional firm, the incentive constraints will be binding at the optimum (see section 2.2). Solving for $\delta_{i}$ in the binding incentive constraints (19) and (20), and substituting back into the left-hand side of the corresponding incentive constraint without $c$ obtains the managers' expected gross rent.

The agency cost is increasing in the ease of trade $\mu$ and decreasing in the price the strong firm has to pay $\tau$. The proposition illustrates the trade-off between the cost and the benefit of redistribution. There is no agency cost in the strong firm if trade is impossible, $\mu=0$, which is our benchmark , or if the price is at its maximum, $\tau=\gamma \alpha$. But in each of these two cases there is also no benefit of redistribution for the strong firm since either it simply does not happen or it is as costly as foregoing second-period production. Note that the situation is a multi-divisional firm is that i) the strong division does not pay a price, $\tau=0$, and ii) the probability of trade is the probability of success in 
the weak division conditional on failure in the strong division, $\mu=p$. In other words, the liquidity of an internal capital market is endogenous and depends on incentives. ${ }^{19}$

We now show that allowing single-divisional firms to trade with each other does not automatically lead to a higher benchmark value than $V^{*}$. A benchmark with trade will in fact do worse than our no-trade benchmark $V^{*}$ if: ${ }^{20}$

$$
p \mu(\tau-\alpha)+(1-p) \mu(\gamma \alpha-\tau) \leq p \frac{c}{p-q} \frac{\mu(\gamma \alpha-\tau)}{p[\gamma \alpha+\mu(\tau-\gamma \alpha)]}
$$

The left-hand side is the joint benefit from trade for both firms and the right-hand side is the cost due to the extra rent captured by the manager of the strong firm. The benefit is increasing in $\mu$ and $\tau$ (assuming that $p>\frac{1}{2}$ ). The cost is also increasing in $\mu$ but decreasing in $\tau$. We therefore conclude that an increases in $\tau$, e.g. more bargaining power for the lending firm, increases the value of trade. More liquid markets, i.e. increases in $\mu$, first increase and then decrease the value of trade. Thus, trade can be harmful if $\mu$ is high and $\tau$ is low.

As in Stein (1997), the model supposes that an internal capital market can a priori add value through efficient redistribution if the multi-divisional firm is financially constrained. This is broadly consistent with the evidence in Hubbard and Palia (1999) who show that the stock market in the 1960s, when capital markets where supposedly less efficient in acquiring and disseminating information, reacted favorably to a merger if a financially constrained firm acquired an unconstrained firm, or vice versa. But at the same time Servaes (1996) finds that conglomerates in the 1960s traded at a discount and Claessens et al. (1999) find that there is no clear pattern of diversification and capital market development across countries.

This might not be inconsistent since the our analysis points out that one could not only have the trade-off between redistribution and incentives in internal but also in external capital markets. For example, an illiquid external market is good for incentives and leads to a higher joint value for the trading firms. In that case, efficient redistribution in an internal capital market could add less value relative to trading firms. Similarly, if funds are expensive then an internal capital markets again could add less value.

\subsection{Diversification: good or bad?}

In this section we explore the empirical implications of our analysis, in particular on the issue of diversification and performance of multi-divisional firms.

\footnotetext{
${ }^{19}$ Note that for an internal capital market the parameter $\mu$ has a slightly different interpretation than for an external capital market. In the former, it captures the availability of resources, which depends on effort, conditional on not having to search for the "trading" counter-party. In the latter is captures transaction costs of trade, e.g. search costs, conditional on counter-parties having resources and looking for trading partners.

${ }^{20}$ Assuming effort in both single-divisional firms that trade.
} 
The first observation is that the internal capital market is active in our analysis. Under redistribution, second-period production in the strong division is positively related to first-period success in the weak division and vice versa. Lamont (1997) and Shin and Stulz (1998) find evidence in support of active internal capital markets. Lamont (1997) documents that in the wake of the 1986 oil price decline, oil companies cut investment not only in their oil also in their non-oil businesses. Shin and Stulz (1998) show more generally that in a conglomerate, division $i$ 's investment tends to be positively related to division $j$ 's cash-flow.

Furthermore, they argue that internal capital markets are inefficient since a division's investment is more sensitive to its own than other divisions' cash-flows. Our analysis however points out that despite the internal capital market being ex-post efficient by assumption (resources are never redistributed from the strong towards the weak division), it may not be ex-ante efficient. The agency costs due to redistribution can lead to underinvestment in the strong division and hence cause a lower crossdivisional investment sensitivity. ${ }^{21}$

So far, our model describes a multi-divisional firms whose divisions are technologically independent and similar but for their future profitability. It might for example be an accurate description for a pharmaceutical conglomerate whose divisions produce different drugs or a manufacturing firm that sells similar products in different countries/regions.

Referring to figure 4, we conclude that such a multi-divisional firm does worst if future profitability is neither very homogeneous nor very heterogeneous across divisions ( $\gamma$ moderate). Headquarter faces a dilemma in that case. On the one hand, the difference in profitability makes redistribution attractive ex-post but it is not attractive enough to overcome the ex-ante agency costs. The dilemma is more acute if it is difficult to incentivize managers ( $c$ high) and incentives do not matter much ( $p-q$ low). In those instances, the conglomerate should, ceteris paribus, be broken up to alleviate the underinvestment in the strong division and reduce rents to managers. ${ }^{22}$ In the example of a pharmaceutical conglomerate this means that ceteris paribus, the appropriate strategy is to develop either a very balanced or a very unbalanced portfolio of drugs (the latter strategy effectively creating cash-cows). Also, if the overall profitability $\alpha$ is feeble, e.g. at the early R\&D stage of production, it is always beneficial to have a portfolio of drugs.

To address the question of how diversification changes the performance of a multi-divisional firm

\footnotetext{
${ }^{21}$ The question whether internal capital markets are efficient or not is controversial in the empirical literature. Scharfstein (1998) and Rajan et al. (2000) conclude that internal capital markets in diversified firms engage in inefficient cross-subsidization, or "corporate socialism". Chevalier (2000) and Whited (1999) question this conclusion on methodological grounds. Maksimovic and Phillips (2002) using plant-level data for manufacturing firms find that resources are reallocated efficiently following demand shocks. Finally, Khanna and Tice (2001) examine the reaction of discount firms to Wal-Mart's entry into their market and show that firms with related diversification make better investment decisions.

${ }^{22}$ Burch and Nanda (2002) find that spinoffs improve value and Gertner et al. (2002) find that spinoffs improve the allocation of capital.
} 
within the context of our analysis, we allow first-period production to be correlated across the two divisions. The correlation is modelled as in Inderst and Müller (2003). Conditional on failure in the strong division, the weak division succeeds with probability $p(1-\rho)$ (and fails with probability $1-p(1-\rho))$ and conditional on success in the strong division, the weak division fails with probability $(1-p)(1-\rho)$ (and succeeds with probability $1-(1-p)(1-\rho))$. The correlation coefficient then is $\rho$. If $\rho=0$ we are back to our initial formulation. We interpret $\rho>0$ as related diversification (it is less likely that the weak division succeeds and the strong fails and vice versa) and $\rho<0$ as unrelated diversification.

The incentive constraint for effort in the strong division conditional on effort in the weak divsion (10) now becomes:

$$
[p+(1-p) p(1-\rho)] \gamma \alpha \delta_{1}-c \geq[q+(1-q) p(1-\rho)] \gamma \alpha \delta_{1}
$$

Similarly, the incentive constraint for effort in the weak division conditional on effort in the strong division now is:

$$
\left[p(1-(1-p)(1-\rho)] \alpha \delta_{2}-c \geq\left[p(1-(1-q)(1-\rho)] \alpha \delta_{2}\right.\right.
$$

Proposition 13 shows that negative (positive) correlation increases (decreases) the agency cost in the strong divisions but decreases (increases) the agency cost in the weak division.

Proposition 13 When first period production is correlated across divisions and $\rho$ denotes the correlation coefficient then the rent for the manager in the strong division is at least $p \frac{c}{p-q}\left(1+\frac{1-\rho}{1-p(1-\rho)}\right)$ and the rent for the manager is the weak division is at least $p \frac{c}{p-q}\left(\frac{\rho}{p(1-\rho)}\right)$.

Proof: As in proposition 5.

When the correlation $\rho$ increases, there is less scope for redistribution since it is less often the case that the strong division fails but the weak succeeds. Consequently, there is less ex-post intervention that hinders incentives in the strong division. But at the same a higher correlation weakens incentives in the weak division since its manager can free-ride on effort in the strong division. Note that $\rho=0$ reduces proposition 13 to proposition 5 .

Comparing the value of a firm whose divisions are correlated to the zero-correlation case $V_{e, e}^{t}$ from (15), correlation adds value if: ${ }^{23}$

$$
-p(1-p)(\gamma-1) \alpha \rho \geq p \frac{c}{p-q}\left(\frac{-1}{1-p(1-\rho)}+\frac{1}{p(1-\rho)}\right) \rho
$$

\footnotetext{
${ }^{23}$ We assume that there is effort in both divisions.
} 
The left-hand side is the redistribution benefit and the right-hand side is the incentive cost of redistribution when production is correlated. The redistribution benefit decreases in $\rho$ and it is positive (negative) if there is unrelated (related) diversification, $\rho<0(\rho>0)$. The incentive cost is a U-shaped function of $\rho$. Under unrelated diversification the cost is positive and decreases in $\rho$. Under strong related diversification, $\rho>1-\frac{1}{2 p}\left(>0\right.$ assuming again $p>\frac{1}{2}$ ), the cost is also positive but increasing in $\rho$. Under mild related diversification however the cost is negative, first decreasing and then increasing in $\rho$.

Numerous studies using different methodologies find that unrelated diversification hurts performance (for example Montgomery and Wernerfelt (1988), Comment and Jarrell (1995) and Rajan et al. (2000)). Our model specifically predicts that unrelated diversification hurts performance if: i) the overall future profitability $(\alpha)$ is low, ii) if future profitability is less heterogeneous across divisions ( $\gamma$ low), iii) if it difficult to incentivize managers ( $c$ high) and iv) incentives do not matter $(p-q$ low).

On the other hand, our analysis can also accommodate evidence that related diversification improves performance (Rumelt (1982) and Khanna and Tice (2001)). ${ }^{24}$ More precisely, related diversification in the context of our analysis improves performance if it is moderate ( $\rho$ low) and if the same conditions hold that make unrelated diversification undesirable.

Using plant level data, Schoar (2002) finds that conglomerates acquire plants that are on average less productive than the average plant within the conglomerate. After the acquisition, the acquired plants experience an increase in productivity whereas existing plants experience a decrease. The author explains this "new toy" effect by invoking a limited attention span by managers. Our model may offer an alternative, rational interpretation. It may be optimal for headquarter not induce effort in the strong division in order to avoid the agency cost of redistribution (see proposition 7). As a result, joining a strong and weak division may lead to productive effort in the latter but not the former which in turn may impact on the future performance of these divisions.

\section{Conclusion}

This paper argues that winner-picking, i.e. the efficient redistribution of scarce funds across divisions in the internal capital market of a multi-divisional firm, has innate agency costs since the funds with which to reward winners ex-post, must be produced ex-ante by division managers. Headquarter's ex-post intervention to pick winners hurts ex-ante incentives in loosing divisions. A manager in a loosing division has lower incentives since he will not be able to reap the fruits of his effort. More

\footnotetext{
${ }^{24}$ The different consequences of diversification on firm value may contribute to the difficulty of drawing on-average conclusions on the value of diversification. Berger and Ofek (1995) and Lang and Stulz (1994) do find evidence of a "diversification" discount but others argue that the discount is tainted by an endogeneity bias (Campa and Kedia (1999) and Villalonga (2000)) or due to a wealth redistribution from shareholders to bondholders (Mansi and Reeb (2002)).
} 
importantly however, picking winners also hurts incentives in winning divisions. A manager in a winning division has lower incentives since he reaps the fruits of somebody else's effort. Even if divisions are technologically independent, headquarter's winner-picking will make them interdependent. As a result, headquarter's investment policy (to pick winners or not) and its incentive policy (how to compensate division managers) are inextricably linked.

The analysis produces a number of testable implications. For example, multi-divisional firms that operate similar but technologically independent divisions should either have a very balanced or a very unbalanced portfolio of divisions. If they do not, they face a dilemma: ex-post redistribution is attractive but not attractive enough to overcome ex-ante agency costs. We confirm that strong unrelated, but also strong related diversification, hurts performance. But we also argue that moderate related diversification improves performance. Furthermore, the agency cost of redistribution may i) lead to managers being paid more than their productivity or the profitability of their division warrants and ii) headquarter deciding not to incentivize managers of strong divisions. Finally, we point out that rewarding divisional managers with options can reduce the agency cost of winner-picking. 


\section{References}

Aggarwal, R. K. and Samwick, A. A. (2003). Why do managers diversify their firms? agency reconsidered. Journal of Finance, page forthcoming.

Aghion, P. and Tirole, J. (1997). Formal and real authority in organizations. Journal of Political Economy, 105:1-29.

Alchian, A. A. (1969). Corporate management and property rights. In Manne, H. G., editor, Economic Policy and the Regulation of Corporate Securities, pages 337-360. American Enterprise Institute.

Berger, P. and Ofek, E. (1995). Diversifications's effect on firm value. Journal of Financial Economics, $37: 39-65$.

Brusco, S. and Panunzi, F. (2000). Reallocation of corporate resources and managerial incentive in internal capital markets. Unpublished manuscript (Universidad Carlos III de Madrid and Universita di Bologna).

Burch, T. R. and Nanda, V. (2002). Divisional diversity and the conglomerate discount: The evidence from spinoffs. Journal of Financial Economics, page forthcoming.

Bushman, R. M., Indjejikian, R. J., and Smith, A. (1995). Aggregate performance measures in business unit manager compensation: The role of intrafirm interdependencies. Journal of Accounting Research, pages 101-128.

Campa, J. and Kedia, S. (1999). Explaining the diversification discount. Working Paper, IESE Business School and Harvard Business School.

Chevalier, J. A. (2000). What do we know about cross-subsidization? evidence from the investment policies of merging firms. Unpublished manuscript(Yale School of Management).

Claessens, S., Djankov, S., Fan, J. P. H., and Lang, H. H. P. (1999). Diversification and efficiency of investment by east asian corporations. World Bank Working Paper 2033.

Comment, R. and Jarrell, G. A. (1995). Corporate focus and stock returns. Journal of Financial Economics, 37:67-87.

De Motta, A. (2002). Managerial incentives and internal capital markets. Journal of Finance, page forthcoming.

Gertner, R. H., Powers, E., and Scharfstein, D. (2002). Learning about internal capital markets from corporate spinoffs. Journal of Finance, page forthcoming. 
Gertner, R. H., Scharfstein, D. S., and Stein, J. C. (1994). Internal versus external capital markets. Quarterly Journal of Economics, 109:1211-1230.

Gromb, D. and Scharfstein, D. (2002). Entrepreneurship in equilibrium. Unpublished manuscript (MIT and London Business School).

Grossman, S. and Hart, O. (1986). The costs and benefits of ownership: a theory of vertical and lateral integration. Journal of Political Economy, 94:691-719.

Hart, O. and Moore, J. (1998). Default and renegotiation: A dynamic model of debt. Quarterly Journal of Economics, 113:1-41.

Hubbard, G. R. and Palia, D. (1999). A reexaminatin of the conglomerate merger wave in the 1960: An internal capital markets view. Journal of Finance, 54:1131-1152.

Inderst, R. and Laux, C. (2000). Incentives in internal capital markets: Capital constraints, competition, and investment opportunities. Working Paper, Universität Mannheim.

Inderst, R. and Müller, H. M. (2003). Internal versus external financing: An optimal contracting approach. Journal of Finance, page forthcoming.

Jensen, M. C. (1986). Agency costs of free cash flow, corporate finance and takeovers. American Economic Review, 76:323-329.

Khanna, N. and Tice, S. (2001). The bright side of internal capital markets. Journal of Finance, $56: 1489-1531$.

Lamont, O. (1997). Cash flow and investment: Evidence from internal capital markets. Journal of Finance, 52:83-109.

Lang, L. H. and Stulz, R. (1994). Tobin's q, corporate diversification and firm performance. Journal of Political Economy, 102:1248-1280.

Maksimovic, V. and Phillips, G. (2002). Do conglomerate firms allocate resources inefficiently? Journal of Finance, 57:721-767.

Mansi, S. A. and Reeb, D. M. (2002). Corporate diversification: What gets discounted? Journal of Finance, page forthcoming.

Montgomery, C. A. (1994). Corporate diversification. Journal of Economic Perspectives, 8:163-178.

Montgomery, C. A. and Wernerfelt, B. (1988). Diversification, ricardian rents, and tobin's. RAND Journal of Economics, 19:623-632. 
Rajan, R., Servaes, H., and Zingales, L. (2000). The cost of diversity: The diversification discount and inefficient investment. Journal of Finance, 55:35-84.

Rotemberg, J. J. and Saloner, G. (1994). Benefits of narrow business strategies. American Economic Review, 84:1330-1349.

Rumelt, R. P. (1982). Diversification strategy and profitability. Strategic Management Journal, 3:359369.

Scharfstein, D. S. (1998). The dark side of internal capital markets II: Evidence from diversified conglomerates. NBER WP 6352.

Scharfstein, D. S. and Stein, J. C. (2000). The dark side of internal capital markets: Divisional rent-seeking and inefficient investment. Journal of Finance, 55:2537-2564.

Schoar, A. (2002). Effects of corporate diversification on productivity. Journal of Finance, 57:forthcoming.

Servaes, H. (1996). The value of diversification during the conglomerate merger wave. Journal of Finance, 51:1201-1225.

Shin, H.-H. and Stulz, R. (1998). Are internal capital markets efficient? Quarterly Journal of Economics, 52:531-553.

Stein, J. C. (1997). Internal capital markets and the competition for corporate resources. Journal of Finance, 52:111-133.

Stein, J. C. (2001). Agency, information and corporate investment. NBER WP W8342.

Stein, J. C. (2002). Information production and capital allocation: Decentralized vs. hierarchical firms. Journal of Finance, 57:1891-1921.

Tirole, J. (2001). Corporate governance. Econometrica, 69:1-35.

Villalonga, B. (2000). Does diversification cause the "diversification discount"? Unpublished manuscript (Harvard Business School).

Whited, T. M. (1999). Is it inefficient investment that causes the diversification discount? Mimeo, University of Iowa.

Williamson, O. E. (1975). Markets and Hierarchies: Analysis and Antitrust Implications. Collier Macmillan Plublishers Inc, New York. 
Wulf, J. (2000). Internal capital markets and firm-level compensation incentives for divsion managers. Unpublished manuscript (Wharton School, University of Pennsylvania).

Yermack, D. (1995). Do corporations award CEO stock options effectively? Journal of Financial Economics, 39:237-269. 


\section{Appendix}

\section{Proof of proposition 1}

(i) Suppose that $p-q \geq c$. If the headquarter wants to liquidate then it sets $\delta_{i}=1$ and $W_{i}=\frac{c}{p}$ ), and exerts effort. This yields a profit of $p-c$ for all values of $\gamma_{i} \alpha$. If the headquarter wants to continue it sets $\left.\delta_{i}=\frac{c}{p \gamma_{i} \alpha}, 1\right)$, and exerts effort iff $\gamma_{i} \alpha \geq \frac{c}{p-q}$. Headquarter's profit in the continuation case therefore is $p \gamma_{i} \alpha-c$ if $\gamma_{i} \alpha \geq \frac{c}{p-q}$ and $q \gamma_{i} \alpha$ if $\gamma_{i} \alpha<\frac{c}{p-q} \leq 1$.

Now if $\gamma_{i} \alpha \geq 1$ headquarter exerts effort when it continues production and the NPV rule holds: $p \gamma_{i} \alpha-c \geq p-c$. If $\gamma_{i} \alpha<1$ then headquarter prefers not to exert effort when it continues if $\gamma_{i} \alpha<\frac{c}{p-q}$. If this condition does not hold then it prefers to exert effort and the NPV rule holds. The highest possible profit from continuation without effort is $q \frac{c}{p-q}$, which is less than the profit from liquidation: $q \frac{c}{p-q}<p-c$.

(ii) Suppose that $p-q<c$. If the headquarter wants to liquidate then it never exerts effort. This yields a profit of $q$ for all values of $\gamma_{i} \alpha$. The liquidation contract $\left(\delta_{i}=1, W_{i}=\frac{c}{p}\right)$ is less profitable that the continuation contract $\left(\delta_{i}=\frac{c}{p \gamma_{i} \alpha}, W_{i}=1\right)$ with headquarter never exerting effort in continuation iff $q \gamma_{i} \alpha \geq q$. Since effort dominates no effort in the continuation case only if $\gamma_{i} \alpha \geq \frac{c}{p-q}>1$ this establishes the NPV rule in this case too.

\section{Proof of proposition 4}

To solve the program (7), headquarter sets $W_{1}=W_{2}=1$ and $\delta_{2}=\frac{c}{(p-q) \alpha}$, so that $\delta_{1}$ is given either by the incentive or the transfer constraint depending on which constraint is more binding. When it is the incentive constraint then $\delta_{1}=\frac{c}{(p-q) \gamma \alpha}$ which is consistent if $\gamma \leq 1+\frac{1}{\alpha}$. Then the value of the firm is $V^{*}$. When it is the transfer constraint then $\delta_{1}=\frac{c}{(p-q) \gamma \alpha}+1-\frac{1}{\gamma}-\frac{1}{\gamma \alpha}$ which is consistent if $\gamma>1+\frac{1}{\alpha}$. Now the value of the firm is:

$$
V_{e^{o}, e}^{n t}=p(2 \alpha+1)-2 p \frac{c}{p-q}
$$

If headquarter wants to induce effort in the strong division only then it sets $W_{1}=W_{2}=1$ and $\delta_{2}=0$, so that $\delta_{1}$ is again given either by the incentive or the transfer constraint depending on which constraint is more binding. When it is the incentive constraint then $\delta_{1}=\frac{c}{(p-q) \gamma \alpha}$ which is consistent if $\gamma \leq 1+\frac{1}{\alpha}\left(1+\frac{c}{p-q}\right)$. Then the value of the firm is:

$$
V_{e, n}^{n t}=p \gamma \alpha+q \alpha-p \frac{c}{p-q}
$$


When it is the transfer constraint then $\delta_{1}=1-\frac{1}{\gamma}-\frac{1}{\gamma \alpha}$ which is consistent if $\gamma>1+\frac{1}{\alpha}\left(1+\frac{c}{p-q}\right)$. Now the value of the firm is

$$
V_{e^{o}, n}^{n t}=p(1+\alpha)+q \alpha
$$

Having effort in the weak division only is always dominated by having effort in both divisions. When $\gamma>1+\frac{1}{\alpha}$ then $\delta_{2}$ cannot satisfy both, the incentive and the transfer constraint (since $\left.\delta_{1}<\frac{c}{(p-q) \gamma \alpha}\right)$. When $\gamma \geq 1+\frac{1}{\alpha}$ however then it possible to induce effort in the strong division without overcompensation.

Similarly, having no effort is always dominated by having effort in the strong division only. When $\gamma>1+\frac{1}{\alpha}\left(1+\frac{c}{p-q}\right)$ then $\delta_{2}$ cannot satisfy both, the incentive and the transfer constraint (since $\left.\delta_{1}<\frac{c}{(p-q) \gamma \alpha}\right)$. When $\gamma \geq 1+\frac{1}{\alpha}\left(1+\frac{c}{p-q}\right)$ however then it possible to induce effort in the strong division without overcompensation.

When $\gamma \leq 1+\frac{1}{\alpha}$ then it is possible to induce effort in both divisions without overcompensation so that the value of the firm is $V^{*}$. The question then is: when $\gamma>1+\frac{1}{\alpha}$ is it better not to incentivize the manager of the weak division? When $1+\frac{1}{\alpha}<\gamma \leq 1+\frac{1}{\alpha}\left(1+\frac{c}{p-q}\right)$ then it is better when $V_{e, n}^{n t}>V_{e^{o}, e}^{n t}$ which can be rewritten as:

$$
\gamma>\left(1+\frac{p-q}{p}\right)+\left(1-\frac{c}{p-q}\right) \frac{1}{\alpha}
$$

When $1+\frac{1}{\alpha}\left(1+\frac{c}{p-q}\right)<\gamma$ then it is better when $V_{e^{o}, n}^{n t}>V_{e^{o}, e}^{n t}$ which can be rewritten as

$$
\alpha<2 \frac{c}{p-q} \frac{p}{p-q}
$$

\section{Proof of proposition 6}

To solve the program (14) headquarter sets $\delta_{1}=\frac{c}{(p-q)(1-p) \gamma \alpha}$. The first continuation constraint $C_{1} \geq 1$ is then satisfied if: $\gamma \geq \frac{1}{\alpha}\left(1+\frac{c}{p-q} \frac{1}{1-p}\right)(*)$.

If $\left(^{*}\right)$ is satisfied then the second continuation and the transfer constraint define a non-empty set $A$ of possible pairs $\left(W_{2}, \delta_{2}\right)$. Also, the marginal rate of substitution of $\delta_{2}$ for $W_{2}$ at which headquarter is indifferent is $\frac{1-p}{p \alpha}$. This is identical to the rate at which headquarter can exchange $\delta_{2}$ for $W_{2}$ with a binding incentive constraint. Thus, if intersection of $A$ with the set of $\left(W_{2}, \delta_{2}\right)$ that satisfy a binding incentive constraint is non-empty, which is the case when $\gamma \geq\left(1+\frac{c}{p-q} \frac{2 p-1}{p(1-p)}\right) \frac{1}{\alpha}$, then the optimal $\left(W_{2}, \delta_{2}\right)$ are given by the binding incentive constraint. When $\gamma<\left(1+\frac{c}{p-q} \frac{2 p-1}{p(1-p)}\right) \frac{1}{\alpha}$ then the incentive constraint does not bind so that $W_{2}=0$ and $\delta_{2}$ is given by the binding transfer constraint. Then the value of the firm is: 


$$
V_{e, e^{o}}^{t}=2 p \gamma \alpha-2 p \frac{c}{p-q} \frac{1}{1-p}
$$

\section{Proof of proposition 7}

If headquarter wants to induce effort in the strong division only then it sets $\delta_{1}=0$ which means that the first continuation constraint is always satisfied. The objective function is $q p\left(C_{1}\left(\delta_{1}\right)+C_{2}\left(\delta_{2}\right)\right)+q(1-p) C_{1}\left(\delta_{1}\right)+(1-q) p\left(C_{1}\left(\delta_{1}\right)-W_{2}\right)$ and the remaining constraints are the second continuation constraint, the transfer constraint, $\gamma \alpha-W_{2} \geq\left(1-\delta_{2}\right) \alpha$, and the incentive constraint: $q \delta_{2} \alpha+(1-q) W_{2} \geq \frac{c}{p-q}$

The second continuation and the transfer constraint define a non-empty set $A$ of possible pairs $\left(W_{2}, \delta_{2}\right)$. Also, the marginal rate of substitution of $\delta_{2}$ for $W_{2}$ is $\frac{1-q}{q \alpha}$ is identical to the rate at which headquarter can exchange $\delta_{2}$ for $W_{2}$ with a binding incentive constraint. Since the intersection of $A$ with the set of $\left(W_{2}, \delta_{2}\right)$ that satisfy a binding incentive constraint is non-empty, the optimal $\left(W_{2}, \delta_{2}\right)$ are given by the binding incentive constraint.

The value of the firm then is:

$$
V_{n, e}^{t}=(p+(1-p) q) \alpha \gamma+p q \alpha-\frac{p c}{(p-q)}
$$

Suppose headquarter wants to induce effort only in the strong division. Under redistribution it is more difficult to incentivize only the manager of the strong division than to incentivize only the manager of the weak division (see proposition 5 and the preceding analysis). But in both cases the objective function is the same. Moreover, it is always possible to induce effort only in the weak division. Hence effort only in the weak division dominates effort only in the strong division.

Given that i) it costs the same to induce effort in the weak division as in a single-divisional firm (see proposition 5 and the preceding analysis) and ii) that effort is desirable (assumption 1), no effort in both divisions is dominated by inducing effort in the weak division only.

The question then is: when does headquarter prefer not to induce effort in the strong division? When $\gamma \leq \frac{1}{\alpha}\left(1+\frac{c}{p-q} \frac{1}{1-p}\right)$ it has no choice since in that case effort in both divisions cannot be implemented. For the remaining parameters, effort in both divisions can be implemented so that we ask: $V_{n, e}^{t}>V_{e, e}^{t}$, or when $\gamma<1+\frac{c}{p-q} \frac{(2 p-1) c}{(1-p) p \alpha}(*)$ then $V_{n, e}^{t}>V_{e, e^{o}}^{t}$, because the manager of the weak division must be overcompensated (see proposition 6). Using the firm values given in (15), the proof of proposition 6 and the preceding analysis, we can rewrite the two equalities as: 


$$
\begin{aligned}
& \gamma \geq \frac{-p}{1-p}+\frac{\left(2 p-p^{2}\right) c}{(p-q)^{2}(1-p)^{2} \alpha} \\
& \gamma \geq \frac{p q}{(p-q+p q)}+\frac{p(1+p) c}{(1-p)(p-q)(p+q-p q) \alpha}
\end{aligned}
$$

The boundaries of the regions defined by the two inequalities and by $\left(^{*}\right)$ intersect at $\alpha=\frac{c}{p-q}\left[\frac{2 p-p^{2}}{(p-q)(1-p)}-\frac{2 p-1}{p}\right]$.

\section{Proof of proposition 11}

Given that $\delta_{i, \alpha}=0$ and $\delta_{i, 0}=0$, the incentive compatibility constraint for the manager of division $i$ is now:

$$
p^{2} \delta_{i, \gamma \alpha+\alpha}(\gamma \alpha+\alpha)+2 p(1-p) \delta_{i, \gamma \alpha}(\gamma \alpha)-c \geq p q \delta_{i, \gamma \alpha+\alpha}(\gamma \alpha+\alpha)+[p(1-q)+(1-p) q] \delta_{i, \gamma \alpha}(\gamma \alpha)
$$

Solving for $\delta_{i, \gamma \alpha+\alpha}$ when the incentive constraint holds as an equality and substituting back into the left-hand side of the constraint to obtain the manager's rent, we get: $p \frac{c}{p-q}+p \gamma \alpha \delta_{i, \gamma \alpha}$ 